\title{
ROLE OF REGIONAL RURAL BANKS IN INDIA
}

\author{
Mr. P. VENKATESWARA RAO ${ }^{1} \&$ Dr. T. UMAMAHESWARA RAO ${ }^{2}$ \\ Research Scholar, Department of MBA, Acharya Nagarjuna University. Guntur, Andhra Pradesh, India
}

Registrar KL University, Vaddeswaram, Guntur, Andhra Pradesh India

\begin{abstract}
India is a country where much revenue generated from rural background since independence, due to more population at rural area. But from industrial developments in India and in view of infrastructure support for industrialisation, urban areas are more focused. So People start migration to urban areas for employment opportunities. Then slowly urban contribution increased and rural economy has disturbed. In this scenario many semi urban and rural area people shifted from their professions and start working in industries. But even from independence till now it is the rural economy contribution to Indian economy is more than urban economy because there is an extended support from different schemes of Govt of India and Banking sector. In particular majority of rural people depended on Rural Banks for their needs in all means. In this regard the researcher has conducted an empirical survey based on secondary sources how rural people supported from Regional rural banks, how bankers are attracted from these people. A detailed study has been done from different sources. Finally concluded the growth of RRBs and their impact on people, and their much attention on technological improvements, and how RRBs prepare their products and install technology with respect of rural entrepreneurs.
\end{abstract}

KEYWORDS: RRBs: Regional Rural Banks Entrepreneurs

Received: Jun 08, 2020; Accepted: Jun 28, 2020; Published: Sep 03, 2020; Paper Id.: IJMPERDJUN20201048

\section{INTRODUCTION}

In India nearly 70 per cent of the population lives in rural areas where since independence, the overall growth rate of population has slowly declined according to the latest censes. Out of 121 crore Indians, 83.3 crore people live in rural areas while 37.7 crore people stay in urban areas."For the first time since independence, the absolute increase in population is more in urban areas than in rural areas. The rural -urban distribution is 68.84 per cent and 31.16 per cent respectively"

The level of urbanisation increased from 27.81percent in the 2001 censes to 31.16 present in the 2011 censes. While the proportion of rural population declined from 72.19 percentto 68.84 percent.During 2001-11 the rate of growth of rural population has been 12.18 present .The growth of the country of rural population was steadily declining since 1991.

For the first time that significant fall of growth rate is seen in the rural areas of EAG states. The EAG (Empowered action Group) States are Rajasthan, Uttrakhand, Bihar Jharkhand, Madhya Pradesh, Chattishghad and Orissa. Rural development before independence can be analysed under two heads (i) development efforts made by British Government and (ii) Efforts made by voluntary organisations. The traditional barter system received a service set-back during the British period. Introduction of cash economy by the breathers enabled the peasants to adopt commercial crops. In this wayagricultural subsistence economy gave rise to commercial crops.During the 
British period the famine took place at regular intervals. The colonial rules felt that the challenge of famine could be successfully met only through irrigation. Subsequently the government appointed the royal commission of agriculture in India in 1926 the commission submitted its report in 1928.Some of the major recommendations of the committee were putting a ban on fragmentation and sub-division of land, establishment of the imperial council of agricultural research etc.To combat the agricultural crisis during the British period, the government adopted several measures such as provision of irrigation facilities, setting up of cooperative societies etc.

\section{RURAL DEVELOPMENT BY WORLD BANK 1975}

"Rural development is a strategy designed to improve the economic and social life of a specific group of people -the rural poor. It involves extending the benefits of development to the poorest among those who seek a livelihood in the rural areas. The group includes small scale farmers, tenants and the landless".

The first five Regional Rural Banks were established on October 2, 1975. By the end of 1976, 40 Regional Rural Banks have been established. In 1978, the government set up a review committee on Regional Rural Banks, headed by M.L. Dantawala. The committee considered that the performance of the regional rural banks was good and that the financial results of the working of some of these banks showed that RRBs have become integral part of the rural credit structure.

\section{RURAL BANK}

Rural bank makes a new development in the rural credit system tailored to the needs of the rural people. "A rural bank may be said as a primary banking institution set up to serve a compact group of villages generally working as a co-operative or as subsidiary bank of a commercial bank, functioning or set in a rural area for the purpose of providing banking and credit facilities in that area. The main purpose of the rural bank is to provide banking and credit facilities to the rural people.

Jurisdiction: The jurisdiction of the each RRB is normally the geographical area of a district sometimes extendable to two or three districts or zones in a state and that of its branches within the districts. The RRBs are established mainly on regional basis only.

Share Capital: According to RRBs Act 1976, the issued capital subscription is 50 per cent from the government of India, 35 per cent from the sponsor bank and 15 per cent from the state government concerned.

\section{OBJECTIVES OF THE STUDY}

1. To study and identify growth and state of RRBs in Indian scenario.

2. To understand and portray the level of penetration of moneylenders in rural area.

3. To identify RRBs encouragement in entrepreneurship in rural areas.

4. Togive a comprehensive suggestions on how to underdeveloped regions should be developed.

\section{RESEARCH METHODOLOGY}

The present study concentrated on $\mathrm{RRB}^{\mathrm{s}}$ and its contributions for rural area development only. For this purpose the researcher have gone through secondary data.The data are collected from annual reports of RBI and NABARD publications including trend and progress of banking in India, statistical tables relating to Regional rural banks in India, articles and papers relating to RBI published in different journals and magazines were studied and data available on interest 
and other sources have also been used. Last 10 years data have been taken (2007-08to 2016-2017).

\section{REVIEW OF LITERATURE}

- The working groupon multi-agency approach in agricultural finance 1976 recommended that regional rural banks are to be preferred because they are better suited to direct financing of farmers.

- Soudamini Nagar 1979 in a study on regional rural banks in Rajasthan found that the regional rural banks had made creditable progress in deposit mobilization and credit distribution.

- Regional rural banks, the reserve bank of India 1982 conducted a study in respect of eleven banks. The report revealed that regional rural banks had successfully maintained their image as a small man's bank by confining their credit facilities to the target group.

- The national bank for agriculture and rural development (NABARD) had commissioned a study on the viability of regional rural banks and entrusted the same to the agricultural finance corporation (1983-84).

- The committee to review arrangements for institutional credit for agriculture and rural development (CRAFICARD) (1982) examined the role of regional rural banks in the rural credit system and recommended that, as regional rural banks were more suitable for rural development work, preference should be given to regional rural banks in regard to licensing of branches in the rural areas.

- Jayaramaiah et.al 2013 confirmed that the overall growth of the economy and povertyalleviation depend upon the system which is providing affordable credit by the financial institutions that stimulates sustainable economic growth through the supply of credit in general and to the rural sector in particular.

- Kuldeep Singh 2014 concludes that the efforts made by RRB in branch expansion, deposit mobilization, rural development and credit deployment in weaker section of rural areas are appreciable.

- Dr. Y.G. Baligatti 2016his study reveals that RRBs have taken initiation to expand their branch network and extending their area of operations, it is witnessed that though the RRBs are successful in providing banking services to unbanked area there is an imbalance growth of RRBs where prominent backward area has been neglected in providing bank credit.

Table 1: Growth of Regional Rural Banks

\begin{tabular}{|c|c|c|c|c|c|c|}
\hline Year & $\begin{array}{l}\text { No.of } \\
\text { RRBs }\end{array}$ & $\begin{array}{c}\text { Growth } \\
\text { Rate }\end{array}$ & $\begin{array}{l}\text { No.of Branches } \\
\text { of RRBs }\end{array}$ & $\begin{array}{c}\text { Growth } \\
\text { Rate }\end{array}$ & $\begin{array}{l}\text { No. of Districts } \\
\text { of RRBs }\end{array}$ & $\begin{array}{l}\text { Growth } \\
\text { Rate }\end{array}$ \\
\hline $2007-2008$ & 91 & -6.2 & 14761 & 1.31 & 594 & 11.23 \\
\hline $2008-2009$ & 86 & -6.49 & 15181 & 2.84 & 617 & 3.87 \\
\hline $2009-2010$ & 82 & -5.65 & 15480 & 1.96 & 618 & 0.16 \\
\hline $2010-2011$ & 82 & 0 & 16001 & 3.36 & 620 & 0.32 \\
\hline 2011-2012 & 82 & 0 & 16909 & 5.67 & 638 & 2.9 \\
\hline $2012-2013$ & 64 & -22.97 & 17861 & 5.63 & 635 & 0.47 \\
\hline 2013-2014 & 57 & -11.84 & 19082 & 6.84 & 642 & 1.1 \\
\hline $2014-2015$ & 56 & -1.7 & 19964 & 4.6 & 642 & 0 \\
\hline $2015-2016$ & 56 & 0 & 20342 & 1.84 & 648 & 0.93 \\
\hline 2016-2017 & 56 & 0 & 20924 & 2.86 & 648 & 0 \\
\hline
\end{tabular}

Source: NABARD, Key Indicators of RRBs for the Year-2017

Growth of Regional Rural Banks in India Number of Regional rural Banks and theirbranch network plays a significant role in improving the performance of RRBs. Availability of Bank branch is considered as one of the most important 
channel of the bank and generally the most preferred channel of customer. Hence it is needed to make an effort by the banks to expand their branch network to provide an equal opportunity to all the users of bank services. The information relating to growth and coverage of Regional rural Banks in India is presented in

Table 1 shows that the number of Regional rural Banks are ranging from 91 to 56 representing with an average of 80 over the study period having a standard deviation and co-efficient variation of 40.30 and 51.38 respectively. The significant observation is the number of RRBs registered continuous declining trend from 91 (2007) to 56 (2017) indicating their negative growth. This phenomenon shall be endorsed to the policy measures initiated by the Government of India towards amalgamation of RRBs in sponsored banks at state level in order to give operational freedom and to improve their financial efficiency and performance.

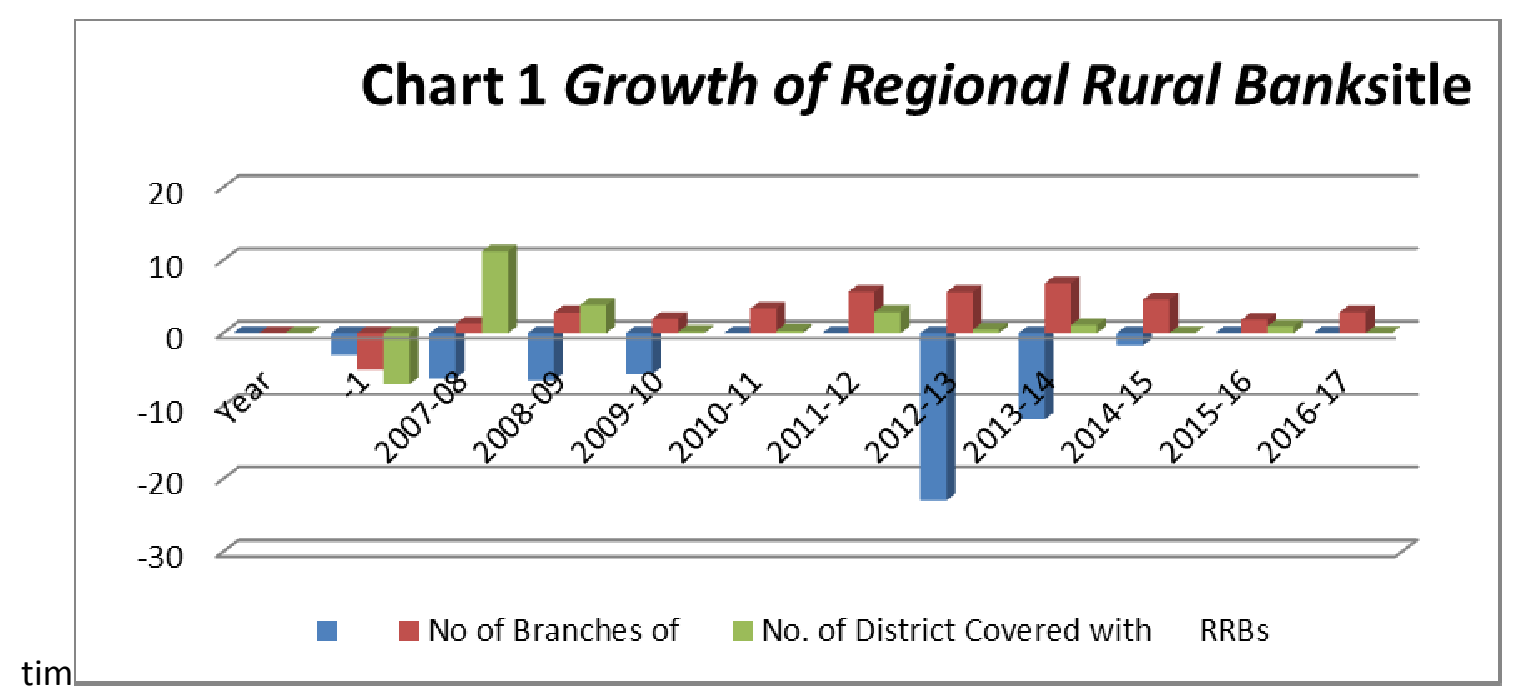

Table 2: Deposits Mobilised and Lending Operations of RRBs(Amount Rs in Crores)

\begin{tabular}{|c|c|c|c|c|c|c|c|}
\hline Year & Deposits & $\begin{array}{c}\text { Increment } \\
\text { In Deposits }\end{array}$ & $\begin{array}{c}\text { Increm } \\
\text { Entin } \\
\text { Deposits }\end{array}$ & Loans/Advances & $\begin{array}{c}\text { Increments } \\
\text { loans and } \\
\text { Advances }\end{array}$ & $\begin{array}{c}\text { \% increment } \\
\text { loans/ } \\
\text { Advances }\end{array}$ & $\begin{array}{c}\text { Credit } \\
\text { Deposit } \\
\text { Ratio }\end{array}$ \\
\hline $\begin{array}{c}2007- \\
08\end{array}$ & $83,143.55$ & $11,814.72$ & 16.56 & $48,492.59$ & $8,780.02$ & 22.11 & 58.32 \\
\hline $\begin{array}{c}2008- \\
09\end{array}$ & $99,093.46$ & $15,949.91$ & 19.18 & $58,984.27$ & $10,491.68$ & 21.64 & 59.52 \\
\hline $\begin{array}{c}2009- \\
10\end{array}$ & $120,189.90$ & $21,096.44$ & 21.29 & $67,802.10$ & $8,817.83$ & 14.95 & 56.41 \\
\hline $\begin{array}{c}2010- \\
11\end{array}$ & $145,034.95$ & $24,845.05$ & 20.67 & $82,819.10$ & $15,017.00$ & 22.15 & 57.10 \\
\hline $\begin{array}{c}2011- \\
12\end{array}$ & $166,232.34$ & $21,197.39$ & 14.62 & $98,917.43$ & $16,098.33$ & 19.44 & 59.51 \\
\hline $\begin{array}{c}2012- \\
13\end{array}$ & $186,336.07$ & $20,103.73$ & 12.09 & $116,384.97$ & $17,467.54$ & 17.66 & 62.46 \\
\hline $\begin{array}{c}2013- \\
14\end{array}$ & $211,488.00$ & $25,151.93$ & 13.50 & $137,078.00$ & $20,693.03$ & 17.78 & 64.82 \\
\hline $\begin{array}{c}2014- \\
15\end{array}$ & $239,494.00$ & $28,006.00$ & 13.24 & $159,406.00$ & $22,328.00$ & 16.29 & 66.56 \\
\hline $\begin{array}{c}2015- \\
16\end{array}$ & $273,018.00$ & $33,524.00$ & 14.00 & $180,955.00$ & $21,549.00$ & 13.52 \\
\hline $\begin{array}{c}2016- \\
17\end{array}$ & $315,048.00$ & $42,030.00$ & 15.39 & $207,279.00$ & $26,324.00$ & 14.55 \\
\hline
\end{tabular}

Source- Reports of NABARD, 2017 
RRB is showing considerable improvement in their lending and deposit performance. The deposit mobilized increased over the period was 8.23 times and lending was 13.10 times and the CD ratio increased to $65.79 \%$ up to $2016-17$. Deposits: Deposit Mobilization is a part of banking services and one of the essential jobs of RRBs. Nonstop and sufficient amount of deposit mobilization will ensure the banks to operate their function of lending and investment on which the success of the bank depends. Being an essential job the table 2 shows that the deposits of RRBs increased from Rs. $83,143.55$ crore in the year 2007 to Rs. 3, 15,048 crore in the year 2016 registering the growth rate $15.39 \%$. The table also enlightens that after merger process the deposits were increased from $16.36 \%$ in 2005 up to $21.29 \%$ in 2009 , but after 2009 the public deposits were start declining.

Loans/Advances: The main motive behind the birth of RRBs is to improve the credit conditions in rural areas and to develop rural economy by providing credit and other banking facilities to the rural population. It is shown in the table 2 that the advances and loans given by all the RRBs in country increased from Rs. 48,492.59 crore in 2007 to Rs. 2 , 07,279 crore in 2016 registering the growth of $14.55 \%$. We can analyse from the table that, merger process not only affect deposits but also loans and advances after 2010 loans and advances were start declining. Credit Deposit Ratio (C/D Ratio): The geneses of RRBs taken place to develop rural economy by providing credit and other banking facilities for the development of agriculture, trade and other productive activities in the rural areas. The credit deposit ratio of the bank indicates the creation of credit out of the deposits mobilized by the banks which has been furnished in Table- 2 . The table exhibits that CD ratio increased from $41.32 \%$ in the year 2007 to $65.79 \%$ in 2017 . There has been consistent growth in the sphere of credit deposit ratio. The year 2014-15 registered a higher rate i.e., $66.56 \%$.

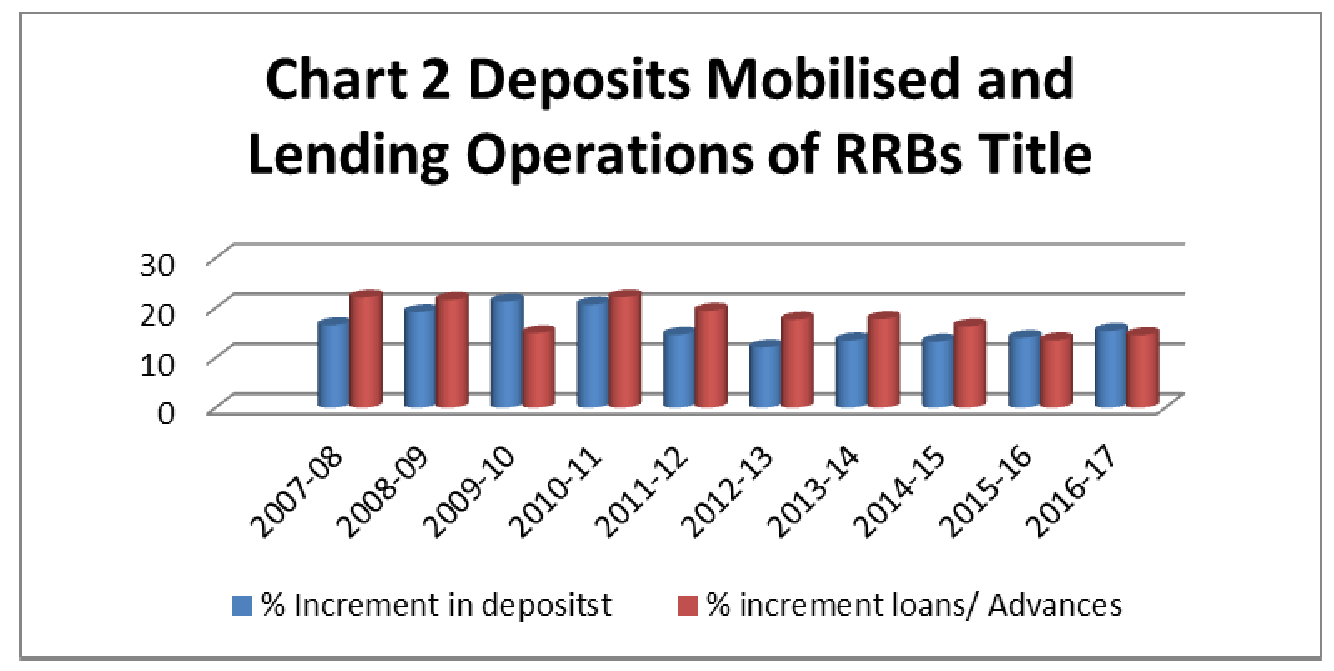

Table 3.3: State-wise Spread of Regional Rural Banks and their net Work and coverage at the end of March, 2009

\begin{tabular}{|c|l|c|c|c|}
\hline SI. No & Name of the State & Number of Rrbs & $\begin{array}{c}\text { Number of } \\
\text { Branches }\end{array}$ & $\begin{array}{c}\text { Number of Districts } \\
\text { Covered }\end{array}$ \\
\hline 1 & Andhra Pradesh & 3 & 1642 & 23 \\
\hline 2 & Arunachal Pradesh & 1 & 30 & 8 \\
\hline 3 & Assam & 2 & 428 & 38 \\
\hline 4 & Bihar & 3 & 1718 & 28 \\
\hline 5 & Chhattisgarh & 3 & 555 & 26 \\
\hline 6 & Gujarat & 3 & 529 & 23 \\
\hline 7 & Haryana & 2 & 507 & 12 \\
\hline 8 & Himachal Pradesh & 2 & 188 & \\
\hline
\end{tabular}




\begin{tabular}{|c|l|c|c|c|}
\hline 9 & Jammu and Kashmir & 2 & 323 & 26 \\
\hline 10 & Jharkhand & 2 & 442 & 24 \\
\hline 11 & Karnataka & 3 & 1460 & 30 \\
\hline 12 & Kerala & 2 & 506 & 50 \\
\hline 13 & Madhya Pradesh & 3 & 1132 & 33 \\
\hline 14 & Maharashtra & 2 & 645 & 9 \\
\hline 15 & Manipur & 1 & 28 & 7 \\
\hline 16 & Meghalaya & 1 & 76 & 8 \\
\hline 17 & Mizoram & 1 & 71 & 7 \\
\hline 18 & Telangana & 2 & 92 & 5 \\
\hline 19 & Nagaland & 1 & 10 & 2 \\
\hline 20 & Orissa & 2 & 901 & 24 \\
\hline 21 & Pondicherry & 1 & 30 & 36 \\
\hline 22 & Punjab & 3 & 311 & 31 \\
\hline 23 & Rajasthan & 3 & 1157 & 8 \\
\hline 24 & Tamilnadu & 2 & 374 & 81 \\
\hline 25 & Tripura & 1 & 133 & 13 \\
\hline 27 & Uttar Pradesh & 8 & 3518 & 18 \\
\hline 27 & Uttaranchal & 1 & 237 & $\mathbf{6 3 5}$ \\
\hline 28 & West Bengal & 3 & 921 & $\mathbf{1 7 8 5 6}$ \\
\hline
\end{tabular}

Source NABARD, Key Indicators of RRBs for the Year-2017

RRBs are expected to ensure that thetargeted rural unbanked location receives the needed credit. Hence it is required an even expansion of the activities of credit over different areas and income strata of the population by opening requisite number of branches in unbanked areas. The information relating to State-wise Spread of Regional Rural Banks and their Network and Coverage is given in Table 2.

Table 2 reveals that the state of Uttar Pradesh is having highest number of RRBs (8) and number of branches 3518 covering highest district (81), followed by Andhra Pradesh number of RRBs (5) number of branches (1630) and number of district covered (23), Karnataka number of RRBs (4), Number of branches (1460) and number of district covered (30), Bihar number of RRBs (3) number of branches 1718 and number of district covered 38), Madhya Pradesh (number of RRBs 3, number of branches (1132) and number of district covered (50) Rajasthan number of RRBs (3) number of branches (1157) and number of district covered (36).

From the above, it is evident that six states (UP, AP, Karnataka, Bihar, MP, Rajasthan) are enjoying the lions share with highest number of RRBs (more than 50\%) covering more number of district with their widen branch network. It is interesting to observe that the share of North Eastern states Manipur, Meghalaya, Mizoram Nagaland, Tripura, Arunachal Pradesh, is insignificant in terms of number of RRBs, number of branches covered, and district covered. The striking observationis that such states are having only one RRB with least number of branches, whereas the state of Nagaland has only 10 branches. It is the clear indication of the imbalance growth of RRBs where the prominent backward areas have been given least priority in providing banking facilities. It reveals the failure of RRBs to cater the credit needs of the backward areas.

\section{Findings:}

- It is found that deposits are increasing in first three years. i.e., from 2007 to 2010. Later

- deposits were decreased gradually upto 2017. Percentage of increments also decreased. 
- From the above data it is understand that the Regional Rural Banks which have been set up

- $\quad$ are good for the development of rural sector and also economy.

- $\quad$ Loans and advances were increased continuously but the percentage is decreased.

\section{Suggestions}

- The RRBs growth is good but the impact on economy is not that much of good as it is not updated with technology in rural area. So technological improvements necessary.

- It is suggested that technological advancements imparting in RRBs along with awareness among people.

- It is suggested that RRBs prepare their products and install technology gith respect of rural entrepreneurs.

- Migrations are the evidence to develop urban area development. So decisions needed to take against to migration lacking with technology.

\section{REFERENCES}

1. Reserve Bank of India, Working Group on Multi-Agency Approach in Agricultural

2. Finance (Karnak Working Group) Mumbai, 1976. p.87

3. Kapre, Abhay Kumar, and Anil Kumar Soni. "A Comparative Study of Regional Rural Banks in Chhattisgarh State." International Journal of Economics, Commerce and Research 3.1 (2013): 79-86.

4. Soudamini Nagar, “Regional Rural Banks: Rajasthan Experience”, Eastern

5. Economist, 72 (24), June 15, 1979, New Delhi, pp 81-83.

6. Dixit, Radhika, and MunmunGhosh. "Financial inclusion for inclusive growth of India-A study of Indian states." International Journal of Business Management \& Research 3.1 (2013): 147-156.

7. Reserve Bank of India, Report on Trend and Progress of Banking in India 1982, p.67.Ibid, p.69.https://www.nabard.org/english/annualreport.asp

8. Kiran, K. PRASANTH, and T. MARY Jones. "Effect of Non Performing Assets On The Profitability of Banks-A Selective study." International Journal of Business and General Management 5.2 (2016): 53-60.

9. Singh, Alka. "Role of Technology in Financial Inclusion." International Journal of Business and General Management 6.5 (2017): 1-6. 

